3reative Commons User License: CC BY-NC-ND Journal of Agricultural Extension

Abstracted by: EBSCOhost, Electronic Journals Service (EJS), Vol. 23 (3) July, 2019

Google Scholar, Journal Seek, Scientific Commons, ISSN(e): 24086851; ISSN(Print); 1119944X

Food and Agricultural Organization (FAO), CABI and Scopus

http://journal.aesonnigeria.org

http://www.ajol.info/index.php/jae

http://eoi.citefactor.org/10.11226/v23i3

Email: editorinchief@aesonnigeria.org

\title{
Farmers' Assessment of the Effectiveness of Extension Communication Methods Used in Ogbomoso Agricultural Zone of Oyo-State, Nigeria https://dx.doi.org/10.4314/iae.v23i3.11
}

\section{Yekinni, Oyedeji. T.}

Department of Agricultural Extension and Rural Development, University of Ibadan, Ibadan, Oyo State, Nigeria.

E-mail: taofeegyekinni@gmail.com

Phone No: $\mathbf{+ 2 3 4 8 0 3 5 9 0 5 3 1 .}$

Afolabi, Christiana. 0.

Department of Agricultural Economics and Extension, Bowen University, Iwo, Osun State, Nigeria.

E-mail: lapsol2k2@yahoo.com Phone No: +2349061916449.

\section{Abstract}

This study assessed the effectiveness of extension communication methods used in disseminating information to farmers in Ogbomoso Agricultural zone of Oyo State. Multi-stage sampling procedure was used to select 120 respondents. Data were analysed using frequency, percentage, standard deviation, mean, median and mode statistics. The findings show that the extension communication methods used for farmers were farm visit (89.2\%) and home visit (78.5\%), contact farmers (73.3\%) and method demonstration (51.7\%). Contact farmers, farm visits and home visit - were the most frequently used communication strategies by extension agencies while farm visit $(x=1.57)$ was the most preferred extension method to receive information and technologies and respondents perceived the extension communication methods used to be moderately effective. The study recommends that extension officers should consider the use of communication methods preferred by the farmers to communicate information to them.

Keyword: Extension service, communication methods, perceived effectiveness

\section{Introduction}

The effectiveness of extension branch is related to communication strategies developed and their applications to bring about social transformation. The term "extension" tends to be associated with agriculture and rural development, cooperative extension, advisory services, technology transfer, as well as the transfer and exchange of practical information (Ahmed, Tadeusz and Piotr (2015). The need for extension services became very necessary in order to provide farmers with development information in order to solve widespread agricultural problems. Bonye, Alfred and (2012) argued that extension 
3reative Commons User License: CC BY-NC-ND

Abstracted by: EBSCOhost, Electronic Journals Service (EJS),

Google Scholar, Journal Seek, Scientific Commons,

Food and Agricultural Organization (FAO), CABI and Scopus

http://eoi.citefactor.org/10.11226/v23i3
Journal of Agricultural Extension

Vol. 23 (3) July, 2019

ISSN(e): 24086851; ISSN(Print); 1119944X

http://journal.aesonnigeria.org

http://www.ajol.info/index.php/jae

Email: editorinchief@aesonnigeria.org

provides a source of information on new technologies for farming communities which when adopted can improve production, incomes and standards of living. Extension service providers make an innovation known to farm households, act as a catalyst to speed up adoption rate and also control change and attempt to prevent some individuals in the system from discontinuing the diffusion process (Alemu, Maetens, Deckers, Bauer and Mathijs 2016).

Extension communication is important because it assists the farmers to be aware of the problems and defining the problems for them and messages on extension communication are always based on farmers experience or agricultural research findings. Usually, there are government information departments responsible for the communication of information between government and the farmers and the public regarding agricultural policies. The success of extension service delivery depends on the expertise and technical know-how of the extension personnel, which could be achieved by providing adequate and relevant information to wide range of farmers who live significantly in the rural areas (Tambari, Abubakar, Attahiru and Moyi, 2014).

Extension teaching methods are devices, modes or channels used to create situations in which new information can pass freely from the source (extension worker or research institutes) to the farming communities (Ayanda, 2019). There are various extension teaching methods used as tools by the extension workers to effect desirable changes in the behaviour of farmers which include; group training, demonstration plot, adopted villages, On -Farm Adaptive Research and mass media (Nwaekpe, Anyaegbunam, Asumugha, Ekwe and Okoye,, 2014).

The most fundamental problems confronting extension delivery in Nigeria is illiteracy levels of farmers, inadequate funding of extension delivery institutions, poor remuneration and provision of transport facility for extension agents to visit the farmers and low ratio of extension agents to farmers (Bello, Agwale and Peter, 2014). The continuity use of traditional farming practices has made the farming community questioned the effectiveness of agricultural extension service to bring about change and accused it of being responsible for stagnation of agricultural development and economic standards of the country. This is due to the fact that Agricultural extension service has been perceived as the fulcrum to revamp and resuscitate the economy through its communicative process of agricultural information for change in attitude and behaviour of farmers towards adoption of innovations. More so, the perpetual food shortage is often blamed on ineffective agricultural research, lack of continuity in agricultural policies and programmes, poor implementation by administrators, low quality of extension and poor linkage system between research, extension and farmers (Adesoji and Aratunde, 2012). 
3reative Commons User License: CC BY-NC-ND

Abstracted by: EBSCOhost, Electronic Journals Service (EJS),

Google Scholar, Journal Seek, Scientific Commons,

Food and Agricultural Organization (FAO), CABI and Scopus

http://eoi.citefactor.org/10.11226/v23i3
Journal of Agricultural Extension

Vol. 23 (3) July, 2019

ISSN(e): 24086851; ISSN(Print); 1119944X

http://journal.aesonnigeria.org

http://www.ajol.info/index.php/jae

Email: editorinchief@aesonnigeria.org

The overall purpose of the study was to evaluate farmers' assessment of effectiveness of extension communication methods used in Ogbomoso South Local government area, of Oyo State, Nigeria. The research objectives were specifically to;

1. identify different extension delivery methods used by the agencies;

2. identify the technological information disseminated through the extension communication methods:

3. determine farmers' preference for different extension communication methods; and

4. determine farmers' perception of the effectiveness of the extension communication methods.

\section{Methodology}

The study was carried out in Ogbomoso agricultural zone of Oyo State, Nigeria. It is located around latitude 8030 'N of the equator and longitude 3054 'S of the Greenwich meridian. The zone comprised of five local government areas namely; Ogbomoso North, Ogbomoso South, Ori-ire, Surulere and Ogo Oluwa. The population of the study includes all the crop farmers' resident in the area. Multi-stage sampling procedure was adopted to select the respondents for the study. Simple random sampling technique was used to select $50 \%$ of the local government areas from the zone to give three local governments. From each of the selected local government areas, $15 \%$ of the farmers were randomly selected from the farmers' lists provided at the local governments. The sample were selected such that 37 farmers were selected from Surulere, 45 from Ogo-Oluwa and 38 farmers Ogbomoso South local government areas to give a total of 120 respondents for the study.

Data were obtained using interview schedule based on the objectives of the study. Extension communication method used and technological information disseminated were measured as "Yes" and "No". Farmers' preference to the extension communication methods was measured on a 3 Likert-type scale of; most preferred (3), somehow preferred (2) and not preferred (0). The values were added up to 3 and divided by 3 to get a mean value of 1.0. Any mean value greater than or equal to 1.0 implies preferred while mean value of less than 1.0 implies not preferred. Farmers' perceived effectiveness of the extension methods used by Agricultural agencies was measured on a 5 point Likert type scale (Strongly Agree, Agree, Undecided, Disagree, Strongly disagree, with scores of 5, 4, 3,2 and 1 assigned respectively. The values were added up to 15 and divided by 5 to get the mean value of 3.0 which was used as cut-off point to determine the effectiveness or ineffectiveness of the extension communication used. The mean score obtained was used to categorise perceived effectiveness into: not effective $(<3.0)$, moderately effective (3.03.5 ) and highly effective (>3.5). Frequency, percentage, standard deviation and the mean were used to analyse the data. 
3reative Commons User License: CC BY-NC-ND Journal of Agricultural Extension

Abstracted by: EBSCOhost, Electronic Journals Service (EJS), Vol. 23 (3) July, 2019

Google Scholar, Journal Seek, Scientific Commons, ISSN(e): 24086851; ISSN(Print); 1119944X

Food and Agricultural Organization (FAO), CABI and Scopus

http://journal.aesonnigeria.org

http://www.ajol.info/index.php/jae

http://eoi.citefactor.org/10.11226/v23i3

Email: editorinchief@aesonnigeria.org

\section{Results and Discussion}

\section{Extension Methods Used to Communicate Farmers}

Table 2 reveals that the extension communication methods used by the extension agents to disseminate agricultural information to respondents in the study area were farm visit $(89.2 \%)$ and home visit $(78.5 \%)$, contact farmers (73.3\%), method demonstration (51.7\%) result demonstration $(42.5 \%)$, radio $(20.0 \%)$ and television $(1.7 \%)$. This suggests that the respondents do not have access to agricultural information through radio and television.

Table 2: Extension communication methods used

\begin{tabular}{lc}
\hline Methods & Percentage $(\mathbf{n}=\mathbf{1 2 0})$ \\
\hline Home visit & 75.8 \\
Farm visit & 89.2 \\
Contact farmer & 73.3 \\
Method demonstration & 51.7 \\
Result demonstration & 42.5 \\
Radio & 20.0 \\
Television & 1.7 \\
\hline
\end{tabular}

*Multiple Responses

\section{Technological Information Disseminated through the Extension Communication Methods}

Results in Table 3 revealed that respondents received information through home visit on seed treatment $(26.0 \%)$, planting cultivation $(24.0 \%)$ and improved variety $(25.0 \%)$. The table also shows that respondents received information through farm visit on fertilizer application (41.0\%) and planting cultivation (30.0\%). The table further reveals that respondents received information through contact farmers on planting cultivation $(62.0 \%)$ and fertilizer application (23.0\%). Majority (56.0\%) of respondents did not receive information through result demonstration and method demonstration (42.0\%) in the study area. This shows that seed treatment, planting cultivation, fertilizer application, agrochemical application and improved variety were the technological information disseminated through the use of extension communication methods. It was deduced that the different communication methods were developed based on the prevailing situations of the farmers. This result implies that the technological information provided were likely needed by farmers in order to solve widespread agricultural problems and improve their productions, incomes and standards of living. 
3reative Commons User License: CC BY-NC-ND Journal of Agricultural Extension

Abstracted by: EBSCOhost, Electronic Journals Service (EJS), Vol. 23 (3) July, 2019

Google Scholar, Journal Seek, Scientific Commons, ISSN(e): 24086851; ISSN(Print); 1119944X

Food and Agricultural Organization (FAO), CABI and Scopus

http://journal.aesonnigeria.org

http://www.ajol.info/index.php/jae

http://eoi.citefactor.org/10.11226/v23i3

Email: editorinchief@aesonnigeria.org

Table 3: Technological information disseminated

\begin{tabular}{lllllll}
\hline $\begin{array}{l}\text { Extension } \\
\text { communicatio } \\
\mathbf{n} \text { methods }\end{array}$ & $\begin{array}{l}\text { Seed } \\
\text { treatmen } \\
\mathbf{t}\end{array}$ & $\begin{array}{l}\text { Planting } \\
\text { cultivatio } \\
\mathbf{n}\end{array}$ & $\begin{array}{l}\text { Fertilizer } \\
\text { applicatio } \\
\mathbf{n}\end{array}$ & $\begin{array}{l}\text { Agroche } \\
\text { mical } \\
\text { applicatio } \\
\mathbf{n}\end{array}$ & $\begin{array}{l}\text { Improved } \\
\text { variety } \\
(\%)\end{array}$ & $\begin{array}{l}\text { No } \\
\text { respons } \\
\mathbf{e}\end{array}$ \\
\hline $\begin{array}{l}\text { Home visit } \\
\text { Farm visit }\end{array}$ & 26.0 & 24.0 & 4.0 & 1.0 & 25.0 & $(\%)$ \\
$\begin{array}{l}\text { Method } \\
\text { demonstration }\end{array}$ & 13.0 & 18.0 & 17.0 & 9.0 & 1.0 & 42.0 \\
$\begin{array}{l}\text { Result } \\
\text { demonstration }\end{array}$ & 2.0 & 12.0 & 13.0 & 12.0 & 5.0 & 56.0 \\
$\begin{array}{l}\text { Contact } \\
\text { farmers }\end{array}$ & 2 & 62.0 & 23.0 & 8.0 & 3.0 & 2.0 \\
\hline
\end{tabular}

\section{Farmers' Preferred Extension Communication Methods}

The results on Table 4 shows that farm visit $(x=1.57)$ was ranked highest as the most preferred extension method to transfer information and technologies, followed by home visit $(x=1.25)$ and contact farmers $(x=1.21)$. This may be as a result of the fact that these methods give farmers opportunity to be active participants during the teaching and learning process as they allow sharing and exchange of information between the agents and the farmers. Television $(x=0.01)$ was the least extension methods preferred by farmers probably because they are mostly unavailable or due to epileptic power supply. Similar results were found by Ahmad, Hussein and Mohammed (2016), in a study on assessing vegetable growers' perceptions of effective extension methods in Jordan, where farm visit was observed as the most preferred method. 
3reative Commons User License: CC BY-NC-ND Abstracted by: EBSCOhost, Electronic Journals Service (EJS), Google Scholar, Journal Seek, Scientific Commons, Food and Agricultural Organization (FAO), CABI and Scopus

http://eoi.citefactor.org/10.11226/v23i3
Journal of Agricultural Extension

Vol. 23 (3) July, 2019

ISSN(e): 24086851; ISSN(Print); 1119944X

http://journal.aesonnigeria.org

http://www.ajol.info/index.php/jae Email: editorinchief@aesonnigeria.org

Table 3: Preferred communication methods

\begin{tabular}{lcc}
$\begin{array}{l}\text { Extension } \\
\text { method }\end{array}$ & Mean $(\overline{\mathbf{x}})$ & Rank \\
\hline Farm visit & 1.57 & $1^{\text {st }}$ \\
Home visit & 1.25 & $2^{\text {nd }}$ \\
Contact farmer & 1.21 & $3^{\text {rd }}$ \\
$\begin{array}{l}\text { Method } \\
\text { demonstration }\end{array}$ & 0.85 & $4^{\text {th }}$ \\
$\begin{array}{l}\text { Result } \\
\text { demonstration }\end{array}$ & 0.63 & $5^{\text {th }}$ \\
Radio & 0.32 & $6^{\text {th }}$ \\
Television & 0.01 & $7^{\text {th }}$ \\
\hline
\end{tabular}

*Multiple Responses

\section{Farmers' Perceived Effectiveness of the Extension Methods Used}

Table 5 indicates that respondents strongly agreed that TV cannot be effective method because it is mostly unavailable $(x=4.08)$ and as well affirmed that farm/ home visit increase their interest in extension message $(x=3.70)$. They also indicated that they like the personalized attention given to them during the farm/home visit $(x=3.54)$ and agreed that contact farmers are very useful because they are easily accessible and reliable $(x=3.28)$. Some farmers indicated that method and result demonstration are practical approaches which make the message clearer $(x=3.01)$. This indicates that most farmers enjoyed receiving information and technologies through these extension methods most especially through farm/home visit and contact farmers because they were perceived to be useful weapons for introducing the findings of modern research in agricultural practices. The result reveals that $60.8 \%$ of respondents assessed the various extension methods used as moderately effective. 
3reative Commons User License: CC BY-NC-ND Journal of Agricultural Extension

Abstracted by: EBSCOhost, Electronic Journals Service (EJS), Vol. 23 (3) July, 2019

Google Scholar, Journal Seek, Scientific Commons,

ISSN(e): 24086851; ISSN(Print); 1119944X

Food and Agricultural Organization (FAO), CABI and Scopus

http://journal.aesonnigeria.org

http://www.ajol.info/index.php/jae

http://eoi.citefactor.org/10.11226/v23i3

Email: editorinchief@aesonnigeria.org

Table 5: Perception of the effectiveness of the extension methods used

\begin{tabular}{lcc}
\hline Perception Statements & Mean $(\mathbf{x})$ & Rank \\
\hline TV cannot be effective method because it is mostly unavailable & $4.08^{* *}$ & $1^{\text {st }}$ \\
Farm/ Home visit increase my interest in extension message & $3.70^{* *}$ & $2^{\text {nd }}$ \\
I like the personalized attention given me during the farm/home visit & $3.54^{* *}$ & $3^{\text {rd }}$ \\
$\begin{array}{l}\text { Contact farmers are very useful because they are easily accessible } \\
\text { and reliable }\end{array}$ & $3.28^{*}$ & $4^{\text {th }}$ \\
$\begin{array}{l}\text { Radio is not effective because of lack of relevance of the extension } \\
\text { message broadcasted }\end{array}$ & $3.25^{*}$ & $5^{\text {th }}$ \\
$\begin{array}{l}\text { Method and result demonstration are practical approaches which } \\
\text { make the message clearer }\end{array}$ & $3.02^{*}$ & $6^{\text {th }}$ \\
$\begin{array}{l}\text { Contact farmers' method is ineffective because they are not } \\
\text { competent to give the message adequately. }\end{array}$ & 2.01 & $7^{\text {th }}$ \\
$\begin{array}{l}\text { Method and result demonstration are usually cumbersome and } \\
\text { utopian }\end{array}$ & 1.99 & $8^{\text {th }}$ \\
$\begin{array}{l}\text { Radio is effective because of wide reach and availability } \\
\text { Farm/home visit and are not effective because of time demanded }\end{array}$ & 1.75 & $9^{\text {th }}$ \\
TV is preferred because of its visual advantages & 0.85 & $10^{\text {th }}$ \\
\hline
\end{tabular}

${ }^{*}$ moderately effective

${ }^{*}$ highly effective

\section{Conclusion and Recommendation}

The study revealed that farm visit, home visit and contact farmers were the most frequent extension methods used by extension agents in disseminating agricultural information to farmers. Farmers' most preferred communication method was farm visits. Seed treatment, planting cultivation, fertilizer application, agrochemical application and improved variety were the technological information disseminated through the use of these extension communication methods. The extension communication methods used were perceived by farmers as moderately effective. Extension performance in result and method was not bad but however, but there is need for improvement. However, extension delivery was poor in radio and television. Appropriate extension methods which provide adequate opportunities for farmers to learn and that stimulate mental and physical activities should be used at all times. There should be regular exposure or trainings of extension workers in communication skills and agricultural technical knowledge to keep them well updated to avoid incompetence. Extension administrators should create conducive environment and as well make fund available for the extension agents so that there can be effective linkage activities through joint priority setting, planning and programming. 
3reative Commons User License: CC BY-NC-ND

Abstracted by: EBSCOhost, Electronic Journals Service (EJS),

Google Scholar, Journal Seek, Scientific Commons,

Food and Agricultural Organization (FAO), CABI and Scopus

http://eoi.citefactor.org/10.11226/v23i3
Journal of Agricultural Extension

Vol. 23 (3) July, 2019

ISSN(e): 24086851; ISSN(Print); 1119944X

http://journal.aesonnigeria.org

http://www.ajol.info/index.php/jae

Email: editorinchief@aesonnigeria.org

\section{References}

Adesoji, S. A., \& Aratunde, T. (2012). Evaluation of the linkage system of research extension farmers in Oyo State, Nigeria: Lesson for agricultural extension administrators. Journal of Agricultural Extension and Rural Development, 4(20): 561-568.

Ahmad, S. A., Mohammed, T., \& Hussein F. A. (2016). Assessing vegetable growers' perceptions of effective extension methods and Information Communication Technologies for training vegetable growers in Jordan. International Journal of Economics and Finance, 8(8):229-236. doi:10.5539/ijef.v8n8p229

Ahmed, A. T., Tadeusz, F., \& Piotr, S. (2015). The role of agricultural extension in the transfer and adoption of agricultural technologies. Asian Journal of Agriculture and Food Sciences, 3(5):500-507.

Alemu, A. E., Maetens, M., Deckers, J., Bauer, H., \& Mathijs, E. (2016). Impact of supply chain coordination on honey farmers' income in Tigray, Northern Ethiopia. Journal of Agricultural and Food Economics, 4(9):1-21.

Ayanda, I. (2019). Rice Farmers Preferred Extension Teaching Methods for Capacity Building in Kwara State, Nigeria Journal of Agricultural Extension, 23(2):1321. doi.org/10.4314/jae.v23i2.2

Bello, D., Agwale, A. O., \& Peter, A. L. (2014). Determinants of information sources used for accessing agricultural innovations by farmers in Western Senatorial zone off Nassarawa state, Nigeria. Proceedings of the $48^{\text {th }}$ annual conference of the agricultural society of Nigeria, Pp.14-17.

Bonye, S. Z., Alfred, K. B., \& Jasaw, G. S. (2012). Promoting community-based extension agents as an alternative approach to formal agricultural extension service delivery in Northern Ghana. Asian Journal of Agric. Rural Dev. 2(1):76-95.

Nwaekpe, J. O., Anyaegbunam, H. N., Asumugha, G, N., Ekwe, K. C., \& Okoye, B. C. (2014). Challenges to the effectiveness of extension methods adopted by national root crops research institute for agricultural technology dissemination in southeast Nigeria. Proceedings of the $48^{\text {th }}$ annual conference of the agricultural society of Nigeria, "Abuja” Pp.93 -97.

Tambari, I. W., Abubakar, B. Z., Attahiru, M., \& Moyi, S. S. (2014). Strengthening the capacity building of extension workers of Sokoto agricultural development 
3reative Commons User License: CC BY-NC-ND

Abstracted by: EBSCOhost, Electronic Journals Service (EJS),

Google Scholar, Journal Seek, Scientific Commons,

Food and Agricultural Organization (FAO), CABI and Scopus

http://eoi.citefactor.org/10.11226/v23i3
Journal of Agricultural Extension

Vol. 23 (3) July, 2019

ISSN(e): 24086851; ISSN(Print); 1119944X

http://journal.aesonnigeria.org

http://www.ajol.info/index.php/jae

Email: editorinchief@aesonnigeria.org

project towards enhancing agricultural transformation agenda in Nigeria. Proceedings of the $48^{\text {th }}$ annual conference of the agricultural society of Nigeria, "Abuja”, Pp. 578 - 581. 